\title{
The Changing Urban Culture and the Role of Water in an Urban Environment - the Case of Vilnius
}

\begin{abstract}
Antanas Stančius
This article attempts to present an overview of the connection between water, seen as an architectural medium, and the culture of Vilnius City. The main purpose is to identify the social and aesthetic role of water for the development of architecture in Vilnius, taking into account the changes in cultural values and concepts pertaining to urban design. In the architecture of Vilnius, water reflects the principles of functionality and artistic concepts characteristic for several different periods. The conclusions reveal that the connection established between water and the Lithuanian cultural identity has been weak, therefore this architectural medium was used more by external forces as a mean of social suggestion, rather than to satisfy the internal needs of the Lithuanian culture. Nevertheless, the discourse that has been forming over the recent years may have a certain potential for future change.
\end{abstract} zation

Keywords: water, architecture, aesthetics, fountains of Vilnius, city culture, urbani-

\section{Introduction}

In traditional Lithuanian culture, owing to the strong self-identification of the Baltic peoples with dry land, few connections can be traced between water and landscape architecture in Lithuanian urban planning, and those that do exist are largely based on a functional approach. The Lithuanian nobility began to use water as an aesthetic element in sculptural fountains rel-

ANTANAS STANČIUS, member of Lithuanian Interdisciplinary Artists' Association, PhD student for Landscape architecture, Klaipeda University, Lithuania; address for correspondence: Architecture, Design and Art Department, Klaipeda University, K. Donelaičio ave. 5, LT-92144 Klaipeda, Lithuania; e-mail stancius.antanas@gmail.com 
atively late, after becoming familiar with the architecture of Western European mansions and with the various trends in landscape enhancement. During the Renaissance, gardens, parks with floral displays, arboreal alleys, pools and fountains were created beside castles or palaces. At the time, most of the architects working in Lithuania were Italian. Three reservoirs equipped with decorative bridges and sculptures were constructed in the luxurious garden around the palace in Vilnius. Water as a decorative element was also used in the compound of the Episcopal Palace compound and in monastery gardens.

The Baroque period imbued Vilnius with a new charm. The Slushko and Sapieha palaces were built in the Antakalnis suburban area, along with magnificent parks that had reservoirs, fountains and ornamental plants. The Classical period saw the development of new principles pertaining to landscape architecture. Later, in the $19^{\text {th }}$ century, the trends of romanticism and historicism began to dominate under the influence of the landscape-style parks designed by the French architect Édouard François André.

With the development of technological society and modernist architecture there evolved two different approaches to the role of water in urban development. The first implies that water is seen only as a functional element and, as a rule, is avoided, so that river and other bodies of water recede into the background on city plans. The second, and opposite approach seeks to include water into the human living environment and integrate it into the public sphere not only as a functional element, but also as an important ecological, aesthetic and psychological factor. This opposition becomes particularly clear in the Sitte and Le Corbusier controversy, which had certain implications for the Lithuanian urban planning discourse.

Due to their patrons and prevailing ideologies, water installations often acquire not a political and cultural, as well as an aesthetic, significance, along with an ideological weight. Over the course of history these realities have intertwined and overlapped with each other, acquiring new forms and ideas, though their primary meaning is lost or is seen from the most convenient contemporary perspectives. Thus, from a superficial point of view, what goes unnoticed is the role of "water culture" as a factor that shapes one's worldview and corrects one's cognition, while the aesthetic side of waterbased facilities is "written off" as politically irrelevant, which is exactly what this study seeks to expose.

Nowadays, while developing the urban perspectives of Vilnius, plans in the sphere of water management are sought to implement alongside new technologies, ecology and art. Modern artlificial water installations are char- 
acterized as closed functional systems that contain various hydraulic equipment intended to achieve a constant, ongoing circulation. These devices consist of two interrelated components: water as such, and the solid forms that give it a definite shape. Although this eventually resulted in the appearance of different morphological types, rather than in the classification of water facilities depending on their shape, size or design, it would be much more efficient to see water, and the effects created with its help, as a basic reference element.

Thus, water-based facilities can be divided into two main groups: facilities with stationary water, and facilities with circulating water. Depending on the effects achieved and the force used as a functional basis for the installation, these two major groups may be divided into smaller subgroups. However, it is not enough to determine the type of a particular water installation in these respects. Indeed, while assessing water installations, one must also take into account the social, historical, aesthetic and technological circumstances.

Purpose of the research: To identify the social and aesthetic aspects of the role water played by water in the development of architecture in Vilnius, taking into account the changing cultural values and concepts related to urban design.

Tasks formulated in order to achieve the purpose: To elaborate on the theme of water in Lithuanian urban culture, to showcase historical influences on Lithuanian water aesthetics, to present an overview of the development of water facilities in Vilnius, along with their social and aesthetic aspects, to define the architectural solutions to the state of the fountains in Vilnius in the context of the new urbanistic aesthetic.

Basic research methods: Textual interpretation, historical reflection, analysis of cartographic materials. The shape taken by water-based facilities in Lithuania has not been studied extensively, while the broader connection between the aesthetic forms of water and the historical context is made on a rather superficial level and tends to be confined to a single periid. The textual interpretation aims to generalize and connect the fragments of information on water that have been studied by researchers but so far remain disjointed, and to connect them to the cultural and historical context.

\section{The Theme of Water in Lithuanian Urban Culture}

In 1930, Paulius Galaune wrote that there was precious little factual information on the use of water in buildings or objects of art in the early Lithuanian culture, although settlements were founded near rivers or lakes. He 
relied on the statements of archaeologists A. Spicinis and L. Ksivickis about Stone Age structures in Lithuania being built on rafts that floated on water or on man-made islands, and connected to land using man-made paths. According to Galaune, the traditional Lithuanian country house and its elements was explored in more detail by German researchers (such as Prof. A. Bezzenbeger), whereas most Lithuanians began to conduct their research as late as 1921. Galaune himself studied separate residential buildings as well as churches, belfries, chapels and synagogues in an architectural context. He does not make any other references to water ${ }^{1}$.

Historians emphaisze the significance of the period of the later Grand Duchy of Lithuania, when the territory under the control of the Lithuanian state stretched from the Baltic to the Black Sea. However, even though Lithuania was a maritime country with plenty of water and access to several seas, it is quite obvious that there were no ports or maritime culture. The Baltic coast had a single minor access point in Palanga, and the ports founded by the Teutonic Order and the Order of the Sword on their own neighboring territories were far larger in comparison. Not even one larger port was founded on the coast of the Black Sea, even after Lithuania came to control a greater stretch of the coastline. Ports had to be rented from the Moldovans, who controlled more than one of them in the vicinity. Thus, apparently, it is not in vain that the emblem on the Lithuanian coat of arms is an armor-clad knight on horseback (known as the Vytis) and that the Lithuanian identity is still confined to the boundaries of dry land. As A. Bumblauskas aptly pointed out, historians are more inclined to refer to the Baltic peoples as the Vikings of dry land ${ }^{2}$.

If one tries to trace the connections between traditional Baltic culture, landscape architecture and water, one will find it difficult to see where these phenomena overlap. During a discussion on the issue, J. Balkevicius strongly maintained that we do not have a tradition of water, while the link between water and architecture is weak, in that architectural structures may be built near the water, but the water is not integrated into them. R. Palys agreed with J. Balkevicius and added that a tradition of water did exist in estates, but the ponds, cascades or fountains found there had been delivered from other countries, while the peasants used undecorated crude ponds for their own

1 P. Galaunè, Lietuvių liaudies menas: jo meniniu formu plètojimosi pagrindai [Lithuanian folk art: the basics of its art forms evolution], L. U. Humanitarinių mokslų fakulteto leidinys, Kaunas 1930, p. 32-35.

2 A. Bumblauskas, Senosios Lietuvos istorija, 1009-1795 [The History of Old Lithuania, 10091795], R. Paknio leidykla, Vilnius 2005, p. 32. 
needs. According to A. Stelbiene, the use of water in Lithuanian architecture has been associated with the classical style formed in southern Europe ${ }^{3}$.

While analyzing the impact of water on the Lithuanian mentality, T. Butkus points out that, while at a certain point in history we used to have an enormous duchy by the sea, the residents were thoroughly uninterested in the coast. For all the rivers and lakes in Lithuania, to a Lithuanian the water or the sea is an object merely to be admired from a distance, and the power of water is perceived exclusively from a visual perspective. Butkus notes that, although all the major Lithuanian cities are situated by the water (the river Neris for Vilnius, the rivers Neris and Nemunas for Kaunas and the sea for Klaipeda), interest in water is strikingly low and superficial. The urban potential of quays and islands, according to Butkus, has so far remained undeveloped and a "water culture", complete with walks along the river bank, is absent altogether ${ }^{4}$.

Seen from a historical viewpoint, no matter what the reason, the water culture of the Baltic cities, with its well-developed trade, international waterways and maritime traditions was still fairly impoverished and poorly developed. Therefore, the Lithuanian culture has failed to create any strong, tradition-based sense of self-identification with water, a sense of identity based on water.

\section{Historical Influences of Western European Culture on the Lithuanian Water Aesthetic}

The first Greek philosophers, while analyzing the origin of the world, asked what was the beginning of the world, i.e., what was it original state. One of the first natural philosophers, the founder of the Milesian school Thales ( 624-547 BC) argued that all things emerged from water ${ }^{5}$ : since water possesses life's power it is the source of nature. Another natural philosopher Heraclitus, who lived at the end of the 6th and the beginning of the 5th $\mathrm{BC}$, announced that, since variability is the most fundamental feature of nature, reality resembles a river, for nobody can step twice into the same waters ${ }^{6}$,

3 A. Štelbienè, Vanduo Lietuvos architektūroje sausumos gyventojo akimis [Water in Lithuanian Architecture in the Eyes of Landsman], "Archiforma”, Ex Arte, no. 4, Vilnius 2000, p. 7580 .

4 T. S. Butkus, Water vision. A view on waterside development in Lithuania, "Project Baltia" 2007, no. 1: Water, PAR OU, Estonia, p. 58-59.

5 T. Aquinus, Apie atskirtąsias substancijas [About Detached Substances], transl. G. Vyšniauskas, Visuomeninè organizacija "LOGOS”, Vilnius 2009, p. 79.

${ }^{6}$ Heraclitus, Fragmentai [Fragments], transl. M. Adomėnas, Aidai, Vilnius 1995, p. 79. 
thus as the source of life and motion, water gives existence to the world and symbolizes the irreversibility of time flow.

In the first book of the Bible the Genesis, it is written that at the beginning "the earth was a formless wasteland, and darkness covered the abyss, while a mighty wind swept over the waters"7. In the second day of creation, God created the vault which separated the water from the land: "Let the waters under the heaven be gathered together unto one place, and let the dry land appear"; and it was so. And God called the dry land "the earth"; and the gathering together of the waters called "the sea" 8 . So water plays important role in the creation process and gives the evidence for God's existence.

The churches use water to baptize, that is to produce Christians. John the Baptizer used Jordan water for baptism and "preached the baptism of repentance for the remission of sins" 9 . During the period of the Church Fathers water was a symbol of baptism. Therefore, the act of baptism could take place everywhere where water is present. In the Middle Ages water was associated with purification and aesthetics. In Medieval aesthetics, thanks to proportions and contrast even ugliness finds its place in the world's harmony. According to scholastic belief, even monsters acquire some dignity as a contrast to beauty and evil becomes useful as the contrast of goodness: in the background of evil goodness shines brighter ${ }^{10}$.

Towns in Lithuania began to develop in the $10^{\text {th }}-11^{\text {th }}$ centuries. The urban plans from that period are characterized by a stable design and radial street networks, although geometric ones occurred as well. In the center of the town there was a square, which usually contained the town well.

The construction of churches and monasteries in Lithuania began in the late $14^{\text {th }}$ and $15^{\text {th }}$ century. In 1469 , Casimir Jagiellonian bestowed a plot on the bank of the Vilnia to the Bernardine monks. The Bernardines converted this marshy and spring-rich stretch of land into a cultivated garden with ponds, canals and fertile vegetable beds. In the $18^{\text {th }}$ century the Bernardine monks restructured the garden into a park, planted exotic trees there and allowed the park to be used by the clergy of Vilnius. Most of the other monastery gardens in Lithuania appeared during the post-Renaissance period.

During the Renaissance, gardens were planted beside castles and palaces, but no historical or iconographic materials have survived as to their

\footnotetext{
7 Gn $1,2$.

${ }^{8} \mathrm{Gn} 1,9-10$.

${ }^{9} \mathrm{Mk} 1,4$.

10 U. Eco, Menas ir grožis viduramžių estetikoje [Art and Beauty in Medieval Aesthetics], transl. J. Vilimas. Baltos lankos, Vilnius 1997, p. 56.
} 
layout. Nothing has remained apart from the fragmentary descriptions in inventory books. It is known that there used to be a representational square and garden by the lower castle. Konstantin Yakovlev-Mateckis claims that "in 1546 , the Italian garden specialist J. Hartulan created a splendid garden by the Royal Palace, complete with representational flower beds, lawns, arboreal alleys and white marble sculptures, as well as three pools, ornamental bridges and other minor architectural objects. Since most of the architects who worked in Lithuania at the time were Italian, one can assume that the small representational gardens planted throughout that period beside the royal palace or the palaces of the wealthy noblemen were designed under the influence of the Italian Renaissance, so one can imagine that water was also used in some way or other. Small representational gardens used to exist beside the Episcopal Palace (the present-day garden area of the Presidential Palace) and the palaces belonging to the noble Radvila (Radziwill), Gostautai and Kiskiai families"11. An Italian monk named Anthony, who visited the place at the time, also tells of a "castle garden", drawing the reader's attention to the style, which had been developed after the Italian model, with lawns, fountains and wells ${ }^{12}$.

Baroque influences began to manifest in Lithuanian architecture earlier than in Poland. New churches (the churches of St. Casimir and St. Theresa), monasteries and estates appeared instead of the old structures, destroyed as a result of war, famine or plague. In the towns, due to the shortage of space, mini-gardens were tended to planted near a building's entrance, while in the countryside, large gardens and parks were created near palace or monastery compounds. As elsewhere in Europe, Baroque parks in Lithuania came in two distrinct designs: the Italian type (terraced, planted in hilly areas) and the French type (planted on a plain). Both types had a geometric plan with a prominent axial composition. The focal point in the composition of these parks, unlike those created during the Renaissance, was the palace, which was built at a somewhat higher altitude than the rest of the park, and the alleys that led toward the palace. Fountains, sculptures, pavilions and other similar structures were built at the intersections between the main and side alleys in order to close their perspectives. The park was also equipped with sophisticated ornamental pools, water cascades, canals, retaining walls, bosquets and elaborate flower beds. It was during this period that the Slushko

11 K. Jakovlevas-Mateckis, Miesto kraštovaizdžio architektūra [Cities Landscape Architecture], Technika, Vilnius 2008, p. 178.

12 J. Balkevičius, Sodu meno stiliu raida [The Development of Gardens Art], Vilniaus dailès akademijos leidykla, Vlnius 2010, p. 169. 
and Sapieha palaces with their magnificent Baroque parks were built in Vilnius, in the suburban area of Antakalnis.

The ensemble of the Slushko Baroque palace and park was constructed in 1691-1694 and designed by the Italian sculptor and architect Giovanni Pietro Peretti. Part of the Antakalnis hill was removed during the construction and an artificial pensinula was created on the river Neris to alter its course. A wide staircase led from the open lot by the palace to the water. The park contained decorative plants and was equipped with reservoirs and fountains. The owner of the palace nailed a marble plaque to the facade with the following inscription: "I have pushed the mountains aside and stilled the vortices of the Neris, I have risen above the tops of the hills as the victor over the brute elements, and, without relying on them, I have become a haven of peace and first monument in Antakalnis"13.

The Baroque ensemble of the palace that belonged to John Casimir Sapieha, Palatine of Wilna (Vilnius), was built near the Slushko palace and is also believed to have been designed by Giovanni Pietro Peretti. The palace park, was transformed several times in keeping with new trends in landscape architecture. Fountains and statues were erected at the intersections between the paths; outside the park the was a small forest or grove with a menagerie and two ponds. Gintaute Dzevalkauskaite-Bysevskiene, who visited the Sapieha palace in 1789, described it in rather vivid terms: "We went to the Sapieha Palace [...] The entire estate has been conceived with royal magnitude. On the outskirts of the forest there is a reservoir used to fill the park ponds through a system of drainage pipes. Situated as they are in front of the main palace stairs, the ponds are a great adornment for the palace. Water is constantly gushing from both the fountains. The park as large as a quarter of the Saxon Park in Warsaw"14. Even today, as one walks through the park, one can see the traces of the geometrical layout and the sites where some of the ponds and fountains used to be. These fountains are also mentioned by historian Jonas Jurkstas ${ }^{15}$. Unfortunately, it is not entirely clear what they looked like.

Thus, water-based facilities played a particularly significant role in the development of Baroque parks. A. Samalavičius emphasizes that "the Baroque era also left quite a few traces of water culture on the territory of the Grand Duchy of Lithuania. Following the example of their Western conuterparts, the wealthy Lithuanian nobility added variety to the gardens and parks in their estates by using natural water bodies. In addition, parks the

\footnotetext{
${ }^{13}$ K. Jakovlevas-Mateckis, Miesto kraštovaizdžio architektūra, op. cit., p. 169.

14 Ibidem, p. 170.

15 J. Jurkštas, Senojo Vilniaus vandenys [Waters of Old Vilnius], Mokslas, Vilnius 1990.
} 
Grand Duchy of Lithuania could be equipped with cascades, ponds were dug out, dams were built and so forth"16.

With the beginning of the Classicist period in Lithuania, new principles pertaining to landscape architecture were formulated. Geometrical layouts were gradually replaced by terrain-based ones, with the main objective being to restore and highlight the natural beauty of the landscape. From the early $17^{\text {th }}$ till the late $19^{\text {th }}$ century, the spaces around city palaces owned by wealthy nobles were still dominated by representational Baroque gardens, and, furthermore, these gardens were planted in monastery courtyards. On the other hand, the parks around countryside estates began to change: the design usually featured a horseshoe-shaped representative square in front of the palace, several lawns and a flower parterre with a fountain or sculpture. Behind the palace there was a recreational area that included a reservoir, some flower beds and decorative shrubs and gradually became a freelydesigned park. Such parks are characterized by curved alleys, paths that repeat the peculiarities of the terrain, lakes, streams and other natural (as opposed to artificially configured) bodies of water, along with water cascades, sculptures and landscape architecture. The Pakruojis Manor and Park in Lithuania are an example of this design. The focal point of the ensemble is a symmetrical palace in the Classicist style, with the compositional axis opposite the palace accentuated by a representational square. Behind the manor house, which is situated next to a bend along the Kruoja river and its impressive islands, lies a landscape park designed after the typical Classicist style. The park allows one to see some unexpected views of the Kruoja river, as well as the islands, the banks and the meadows on them, all of which are important compositional elements.

Later, in the middle of the $19^{\text {th }}$ and in the $20^{\text {th }}$ centuries, historicism and romanticism, tendencies that arose in Lithuania with a delay compared to the rest of Europe, became dominant. Of particular importance for the artistic development of parks during this period were the activities of the French theorist, botanist and landscape architect Édouard François André (18401911). He formulated a novel set of principles for park development that was based on human physiological needs and expanded the eclectic park development trend prevalent at the time. E. F. André focused on pictorial accents and on the close connections between the landscape and architectural elements, arguing that it was essential to find integrity in a diverse environment

16 A. Samalavičius, Idejos ir struktūros architektūros istorijoje [Ideas and Structures of Architectural History], Kultūros barai, Vilnius 2004, p. 165. 
or an ensemble. A. Maciulis claims that the parks created by E. F. André are valuable for the Lithuanian culture and architecture as a whole ${ }^{17}$.

The first aesthetic water installations in Lithuania could be found in parks, but they were grounded in a Christian worldview, such as the dogma of the Bernardine monastic order. Little is known about the water-based facilities that existed during the Renaissance, but it is clear that they were influenced by the outlook of the great Italian artists, if not the Pope himself. On the other hand, in the eyes of their contemporaries, Baroque parks were more associated with the cultural influence of Warsaw rather than with any unique cultural achievements, and, later, with the classical tendencies that originated in Western Europe. Finally, the Lithuanian aesthetic taste was heavily influenced by the Frenchman E. F. Andre.

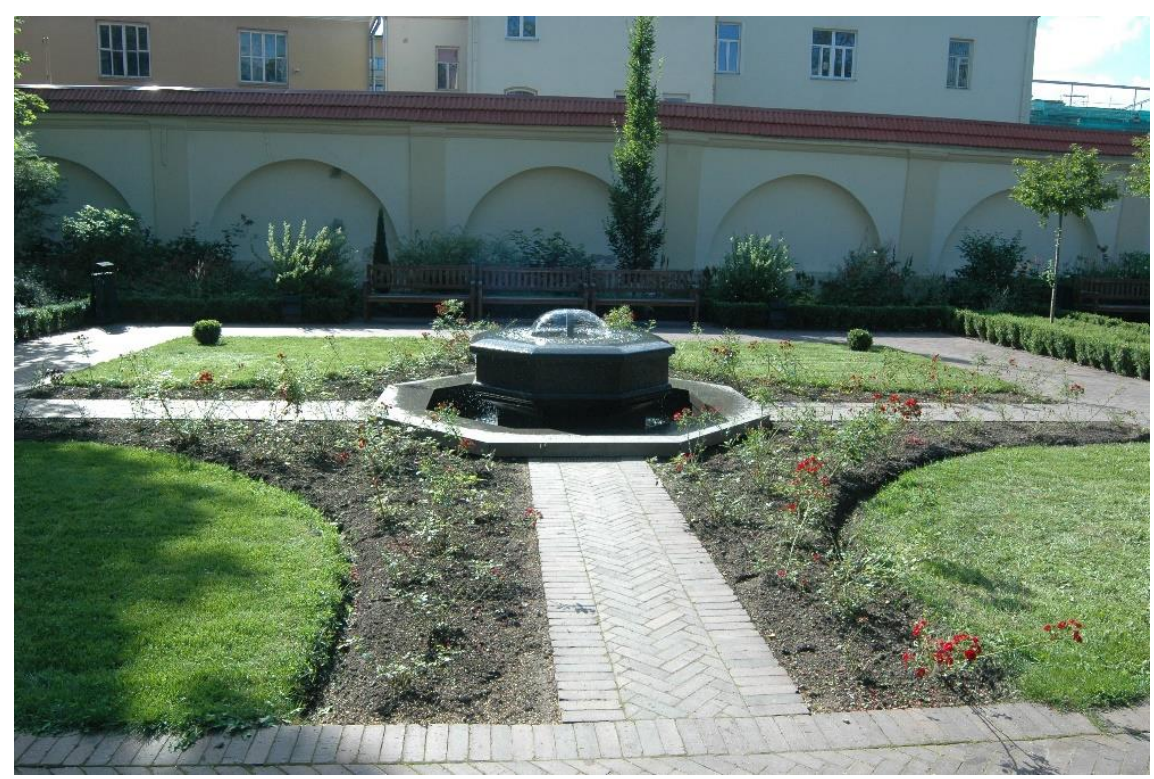

Fountain in Bernardinai Garden Vilnius, photo by A. Stančius

\section{The Social and Aesthetic Aspects of the Development of Water Installations in Vilnius}

It is known that a public water supply system was already available in the $16^{\text {th }}$ century in Vilnius, but most of the city's inhabitants chose to use the public water wells, as plumbing pipes remained a rare phenomenon and were used by the wealthier urban dwellers. At the time, there were several

${ }^{17}$ A. Mačiulis, Architektūra - stiliai, kompozicija, menų sq̨veika [Architecture - Styles, Composition, Art Interaction], VDA leidykla, Vilnius 1997, p. 34. 
well-known public water wells in Vilnius, excavated or connected to the pipeline, which were referred to as public pipes or "chests" in the $17^{\text {th }}$ and as fountains in the $19^{\text {th }}$ century. The exact structure of these wells is unknown, but it is most likely that the water used to flow through the pipe and directly into the reservoir, which would confirm that water-based facilities had a utilitarian function ${ }^{18}$. Even though this used to be an important part of the urban infrastructure, only the sketches or plans of these devices have survived. Contemporaries did not pay sufficient attention to water-based facilities as a part of their everyday lives. It is known that the more sophisticated wells had a wooden crib and shaft and were covered with a wooden plate. The oldest surviving water installations in public places date back to the $19^{\text {th }}$ century and testify to the rapid urban development in Lithuania at the time, which caused a shortage of fresh water. This led to the design and development of centralized water supply systems, and, as a consequence, many of the old waterworks became obsolete and were dismantled, though some were replaced by new, more complex and sophisticated water installations.

One such example is the Town Hall Square. On F. Hogenberg's plan, which dates back to 1545 and has survived to this day, one can clearly identify the site of a former well. However, the plan is very abstract, and, since the well has not been preserved, it is difficult to tell what the shape or composition with relation to the town square might have been like. Traditionally, the square was used to hold various festivals and markets, or to announce government decisions. The public well that existed in the square and was connected to the general water supply system would receive water through wooden pipes from sources situated further away. Finally, at the start of the $20^{\text {th }}$ century, a fountain was constructed in the square, which was more akin to a park or garden at the time. It was planted with trees, lawns and other greenery, which is rather untypical compared to the traditional multifunctional central squares in Western European cities. Later, over the course of the troubled $20^{\text {th }}$ century, the square went through various transformations. In 2006-2008 the square was reconstructed in accordance with a project prepared by "Archinova", which involved the designing of an octagonal fountain and a column for drinking water standing next to each other. A similar potable water column can be found in Uzupis Square and marks the site of a public well that was once used by the townspeople.

18 J. Jurkštas, Senojo Vilniaus vandenys, op. cit., p. 95. 


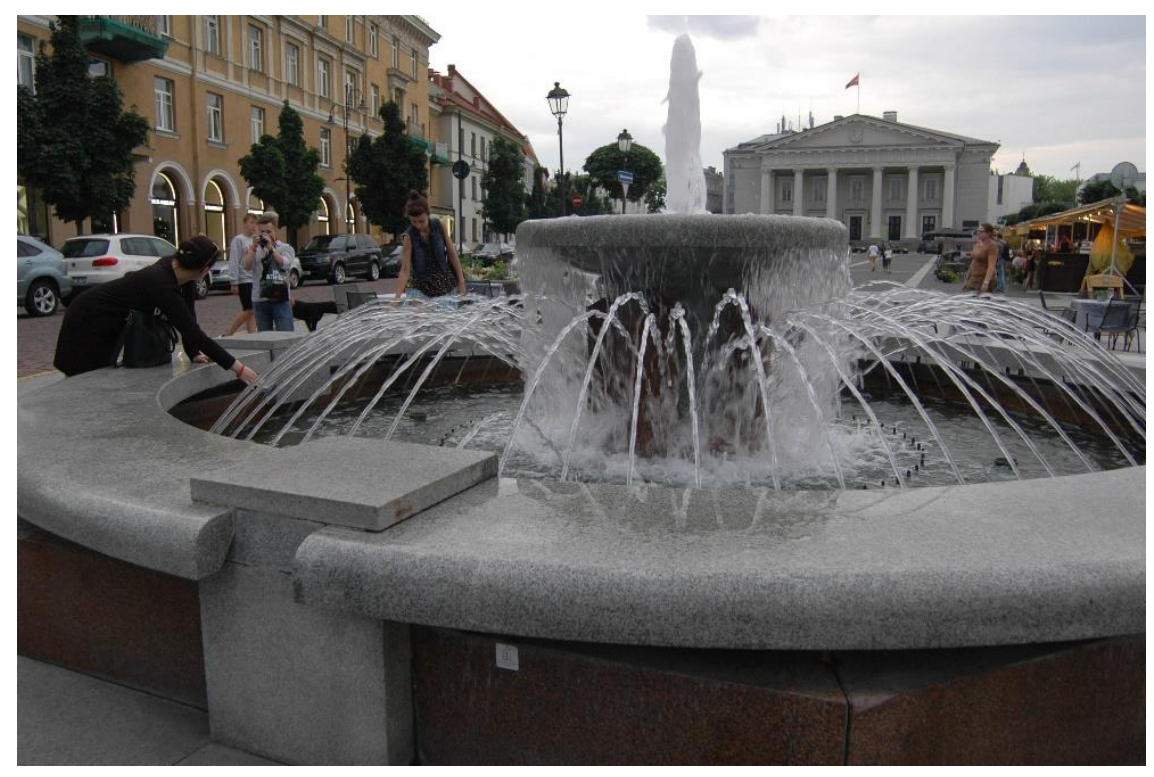

Fountain in Town Hall Square Vilnius, photo by A. Strančius

One of the first decorative water installations to be created in a public area in Vilnius was the fountain built in 1853 in front of the Governor General's Palace (now the Daukanto Square). By then, a square had already been formed on the site, whereas the main water supply line from the Vingriai springs had been constructed much earlier, but there is no concrete evidence to confirm that there used to be any water-based facilities before then. From the fountain estimate dating back to 1871, we know that the reservoir was constructed from masonry, cemented with plaster and painted in stone-colored oils, and we can see what it used to look like on the surviving photographs. The city authorities paid considerable attention to the fountain, constantly renovating it and ensuring proper drainage. By then, the rest of the city's water supply system had undergone a marked deterioration. Unfortunately, this fountain existed only until the beginning of the $20^{\text {th }}$ century and was then replaced with a monument to M. N. Muravyov ${ }^{19}$. However, in the late $20^{\text {th }}$ century there were plans to revive the fountain, although not quite in the same location - more precisely, in the courtyard of the Presidential Palace ensemble. The construction began under President Algirdas Brazauskas, with Audrone Lainauskaite being the author of the project. To date, most of the preliminary tasks have already been carried out: a granite cup has been shaped and other technical solutions applied, but when Valdas Adamkus became head of state, further work on the reconstruction of the Presidetial Palace ensemble was suspended and a banal flower bed was planted on the site that had previously been designated for the fountain.

19 Ibidem, p. 71. 
Half a century of dependence on the Soviet Union could not have passed without leaving some distinct marks, as every attempt was made throughout that period to destroy the Lithuanian national identity. Though quite a few new water installations were built in the town squares, there had been a drastic shift in their inner content and meaning. Most public areas took on traits that used to be uncharacteristic for Lithuanian town squares, among them the presence of large water installations that cover a considerable portion of the square, fracturing and reducing the public area.

Water installations created in the late $20^{\text {th }}$ century, during the Soviet occupation, are characterized by laconic, clear geometric and architectural forms and a neglect of the symbolism peculiar to Lithuania. In some public areas, somewhat more decorative water installations were created using better materials and a more sophisticated design that could include an original sculpture or sculptural composition created by an artist. However, these water installations were scarce and the symbolism they used was foreign to our country, and, rather, served to represent an alien ideology. It should be noted that the post-Soviet fountains and recreational areas that have been preserved into the present are relatively neglected, especially if one bears in mind that, as far as the design of recreational areas was concerned, this was one of the more productive periods in our architectural history. The solutions applied at present, such as transforming fountains into flower beds, are questionable expediency-wise and can only be temporary.

Another striking example of the Soviet period is the fountain in Independence Square in Vilnius, built in 1984 during the reconstruction of the square in accordance with a project by A. Nasvytis. The fountain was designed by sculptor G. Karalius. The impressively-sized reservoir occupies a large part of the square and is equipped with a vertical pyramid-shaped element that spews water. In the past, ducks would refresh themselves in the reservoir and the townspeople would come to sit by the fountain, but later on the square and the fountain itself came to be considerably neglected.

Finally, in 2013 the defunct fountain was buried in soil and planted with flowers in haste on the grounds that Lithuania, which was elected chair of the European Union at the time, was preparing to receive delegations from abroad and the non-functional and neglected fountain did not appear to be a representative element. Although the architectural composition of the fountain had been included in textbooks on art and architecture and had clearly been designed to form a continuous whole with the immediate urban environment, there have been no plans to restore it so far.

As far as functional qualities are concerned, the fountain by the Seimas was advanced from a technological perspective, was not distinguished by a 
high operating cost and could have achieved a certain aesthetic effect even while dormant - the requisite visual component would be provided by the ripples on the surface of the water and the resulting reflections.

By now, quite a few such solutions (for instance, converting this or that water reservoir into a flower bed) have already been implemented in the Lithuanian capital. A large part of the existing water-based facilities in the city have been forgotten and neglected. It is difficult to give a definite answer as to the reasons behind this situation, but one suspects that there are several factors intertwined here, including the historical and economic paradigm and even the poor understanding of the aesthetics of water.

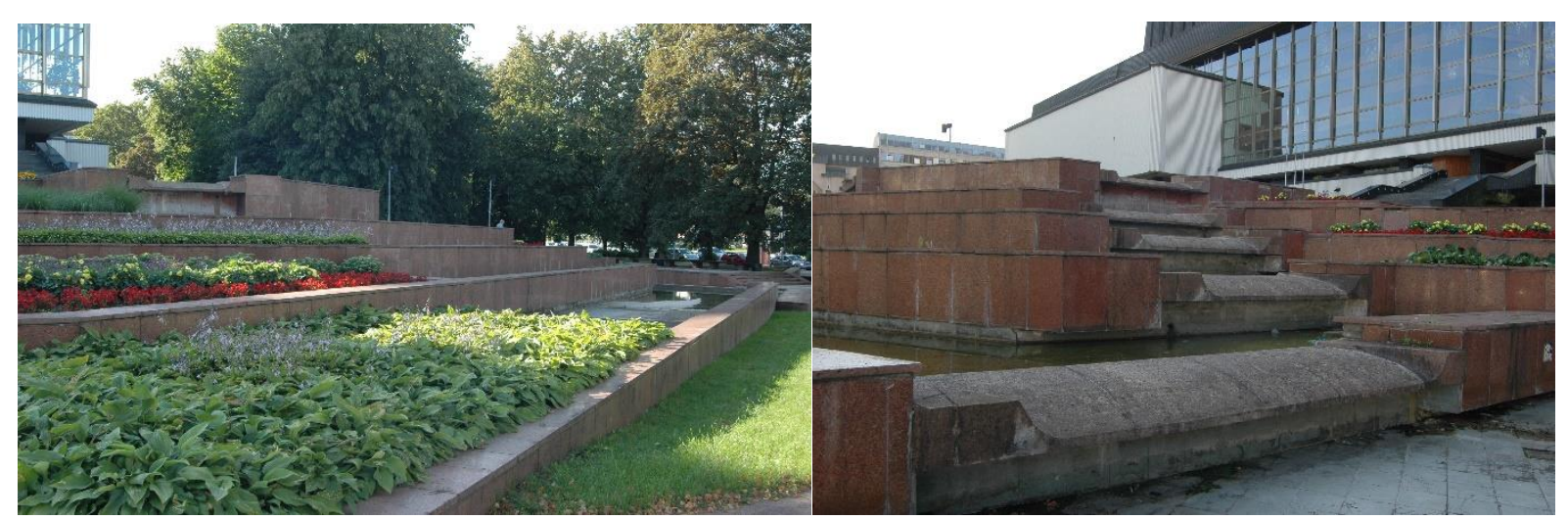

Abandoned fountain near Lithuanian National Opera and Ballet Theatre in Vilnius, photo by A. Stančius

According to Audrius Novickas, "water installations probably are the oldest structural elements of a square to be used as memorial signs" 20 , and their longevity is due to their practical and functional significance for the urban population. However, from the late $19^{\text {th }}$ century onwards, water supply systems began to develop in the cities and other sources of fresh water gradually lost their purpose, though they were retained as a tangible symbol of the quality, status and significance of the given environment. Since the Renaissance, the water-based facilities constructed in squares were often decorated with a statue of the city patron. This would help encourage a sense of community and civic spirit among the inhabitants. During the Baroque era, a tendency was revealed to increase the number of reservoirs, to open the water tanks and position them in the central part of the town square. The period

20 A. Novickas, Atminties iprasminimas miesto aikštèje: nuo paminklo iki patirčiu erdvès [Memory-Actualization in the Town Square: from the Monument to the Experiences of Space], Technika, Vilnius 2010, p. 45. 
saw a rise in the popularity of the components used to highlight the horizontal axis of a water installation, which are to be treated as symbols of the feminine element - for example, the baptismal font, the womb, spiritual refuge or sanctuary. The vertical components, on the other hand, represented the male element, such as searching and mediation between heavenly and earthly forms. Some hints of this symbolism can be traced in the basin and pyramid structure, such as the one used for the fountain in Independence Square in Vilnius ${ }^{21}$.

Thus the city authorities and the representatives of ecclesiastical or commercial bodies have employed water installations as emblems of power, might, prosperity and glory. To achieve this objective, a wide range of different expressive forms and devices may be used. For example, a common practice in Western Europe was to use classical myths that reflected these themes. Nevertheless, fountains not only have an aesthetic charm, but also demonstrate the level of progress in hydraulics and engineering, which is what enables one to move water from one location to another. Often, these projects require plenty of investment, both with regard to labor force and finances, and the funding of such projects grants as much honor as the completed facility itself. In this sense, the propagandist meaning of a fountain may not be immediately apparent ${ }^{22}$.

However, when water is perceived exclusively as a symbol of power, its aesthetic value is lost. Modern urban planners devalued water and rejected its aesthetic function. For instance, the French architect Le Corbusier spoke out with a particular vehemence against the presence of water sources in modern cities, arguing that urban planning should be based on technological, rather than aesthetic, principles ${ }^{23}$.

Urban development changes a city's image. However, as noted by Roger Scruton, the modern city has failed because aesthetic principles were not taken into consideration. Scruton argues that urban development "schemes are often controlled by people who do not understand aesthetic principles and have no desire to take interest in them" 24 . In developing the geometrical structure of a city, the modernists failed to take into account its heritage and

\footnotetext{
${ }^{21}$ Ibidem, p. 45-49. 77-105.

${ }^{22}$ M. Symmes, Fountains Splash and Spectacle, Smithsonian Institution, Singapore 1998, p.

${ }^{23}$ Le Corbusier, The City of Tomorrow and Its Planning, The Architectural Press, London 1947.

24 A. Samalavičius, Nelaisvés formos. Almanto Samalavičiaus pokalbiai apie ekonomika, miestokūra ir krizes [Captivity Shape. Almantas Samalvicius Talks About Economy, City Development and Crisis], Kultūros barai, Vilnius 2014, p. 135.
} 
historical traditions. As a result, such cities lost their individual character, identity and aesthetic charm.

While assessing the legacy of the Soviet period, one should take into account the trends that were prevalent at the time. J. Minkevicius notes that the search for a unique national identity, which was dominant in the independent Lithuanian state, was confronted with a grave situation from both the cultural and the ideological point of view. The crisis was caused by two major stumbling blocks - the Soviet political occupation that destroyed national independence, and the social, cultural and economic conditions imposed by force through obligatory government directives. Nevertheless, it is quite apparent that "architecture has become the field that served to encode and transmit information about the strength of the national spirit and the nation's defiance and refusal to reconcile with its historical destiny"25. Seen in this light, fountains are revealed to reflect the spirit of a historical era. Thomas S. Butkus claims that, during the Soviet era, fountains and other architectural accents were a means to confirm and legitimize a Lithuanianized sense of identity, which points at the maturity of the architect community. These costructions were the most vivid reflection of the progress achieved by socialist cities, and were widely promoted in the illustrated journals of the time ${ }^{26}$.

One ought to reconsider water-based facilities with regard to the social, historical, aesthetic and functional circumstances. Of course, the water-based facilities have an aesthetic value of their own, if they are attuned to the environment, but the aesthetic aspect as such is not the most important point. The simplest water-based facility can serve as a place of refreshment point and a source of drinking water. From a commercial standpoint, these facilities can be characterized by a an entertaining and enjoyable quality, and, of course, water-based facilities can serve as an "urban oasis" and protect one from the oppressive impact of the city. In addition, a water installation may be a permanent or temporary representative element. Many of the more famous installations have also have a metaphorical significance, such as a religious one, and water facilities can also be a tool for propaganda ${ }^{27}$. All of these aspects, taken together or separately, serve to a greater or lesser extent to enhance socialization, promote a community spirit and an exchange of ideas.

25 G. Skripkiūnas, Statyba ir architektūra [Construction and Architecture], Proceedings of the Conference, Technologija, Kaunas 1998, p. 46-48.

${ }^{26}$ Miesto architektūra. Erdvès, formatai, akcentai [Urban Architecture Spaces, Formants and Accents], "Acta Academia Artium Vilnensis" 2015, vol. 76, Vilniaus dailès akademijos leidykla, Vilnius 2015, p. 136.

27 M. Symmes, Fountains Splash and Spectacle, op. cit. 
Artificial water installations also have some economic and technological aspects. In assessing the role of water, one must identify and examine all of these circumstances as a whole.

The presence of water installations in the public squares of Vilnius has been recorded historically, but the more ornamental fountains began to appear relatively recently and could not avoid the various ideological influences experienced by the country as a whole. The fountains that appeared during both the Tsarist and the Soviet periods had a certain charge of propagandist or ideological power. Still, the fountains, as socially active elements, enabled their creators to channel metaphorical ideas, including those related to political resistance. However, once the political realities changed, the importance of fountains was reduced, whether consciously or not, and economic considerations came to the fore.

\section{Aspects of the Architectural Solutions Applied to Water Installations in Contemporary Vilnius}

According to Ingrida Jakubaviciene, until today, Lithuanian cities are being shaped more in a theoretical sense: "The image of the city is portrayed as a sort of dead emblem that may involve various components, one forgets that the city is alive, that it has a face and spirit of its own"28.

Urban spaces that are attractive from an emotional point of view are created by landscape architects, designers, sculptors and other artists, who expand the functionality and perception of these spaces. For instance, Jekaterina Lavrinec gives a project by designer Mantas Lesauskas, titled "Let us revive the fountains of Vilnius", implemented in 2008, as an example of attempts to regenerate the public areas in Vilnius ${ }^{29}$. During the implementation of the project, Lesauskas constructed seats made from tires around the defunct fountain in Independence Square. According to Lavrinec, such an installation "identifies and reveals the potential of urban areas and encourages the townspeople to be more proactive, whereas their viability depends on the people's own ability and courage to take advantage of existing opportunities"30.

${ }^{28}$ I. Jakubavičienè, Vartotojiškos visuomenès kuriamas Lietuvos miesto įvaizdis [Lithuanians City Image Created by Consuming Society], [in:] Kultūra ir miestas. Mokslinių straipsnių rinkinys, ed. Rimkutė A., Vilniaus universitetas, Vilnius. 2011, p. 91.

${ }^{29}$ J. Lavrinec, Urbanistinè choreografija: kūnas, emocijos, ritualai [Urban Choreography: Body, Emotions, Rituals], "Santalka: Filosofija, Komunikacija” 2011, vol. 19, no. 1, LMA leidykla, Vilnius 2011, p. 62-73.

30 Ibidem, p. 69. 
However, considering the idea of creative city and rethinking what is creative city it's impossible to avoid all sorts of contradictions. Discussing more abstract, any city, which attracts and stimulates creative ideas is creative. On the other hand, it is possible to compare cities in accordance with attraction to creative persons, thought who are very individual and whose needs and priorities could differ very much. Therefore, city must offer creative spaces - such that would be appealing for creative individuals. The city space is like tightly divided between creative communities which works intensively there. Most likely the sign of city's creativity is not the ability to attract creative persons, but how much it intentionally develops, how much the policy of creativity is cultivated and which could grow independently ${ }^{31}$.

In an attempt to foster the uniqueness of the capital, the Municipality of Vilnius City decided to involve foreign experts in a discussion about public areas in the existing urban context. For this purpose, the municipality decided to participate in the iniative "B-Team - Expert Assistance in Brownfield Conversion", sponsored by the European Regional Development Fund under the INTERREG IVC program. The initiative involved the creative workshop $B$ team-Vilnius 2011, whose participants included 50 professionals from different countries, divided into 6 groups depending on the topic they were to address. Each group contained representatives from the Lithuanian universities, communities, the Municipality of Vilnius, investors responsible for planning further development, experts in heritage protection and ecology. The debate took place revolved around the so-called "Architectural Park", i.e. a derelict area of 78 hectares between the Old Town of Vilnius and the Pavilniai Regional Park, and its re-integration into city life. Paupys, a historic industrial district that was known since the $16^{\text {th }}$ century as Paplauja, used to be among the most beautiful suburbs of Vilnius owing to the landscape, the river Vilnele, the canals and adjacent gardens. Its structure was completely destroyed by the construction that took place during the Soviet era: after World War II, the territory turned into an industrial district.

Ecosphere exposed to environmental pollution is quite a challenge for creative community. However, the society is oriented into creative perspective and not only to survival needs. The problem is that consuming society is driven into the search of bigger comfort debilitates social and natural environment and in such ways, reaches opposite goal - discomfort. It doesn't matter if there is developed creative policy or not, politicians create certain conditions for creative communities. But every system loses its creative potential when it becomes treated formal. Thus, every system is in the most

31 T. Kačerauskas, A. Kaklauskas, Kürybinis miestas: mitai ir utopijos [Creative City: the Myths and Utopias], "Filosofija Sociologija” 2015, vol. 25, no. 3, LMA leidykla, Vilnius, p. 190-199. 
creative state at its incubation period, while remaining informal and demanding of change of social and physical environment ${ }^{32}$.

The creative workshop group "Landscape" ("Krastovaizdis"), with Gintaras Stauskis, a professor at VGTU, as the moderator, proposed a specific water management scheme that could be used to design the landscape of the Paupys territory: "to find innovative solutions for rainwater collection; to rediscover the traditional systems for the collection and management of rainwater; the swampy lowlands, streams, ponds and lakes situated near the street lines and public spaces; re-discover the following traditions: public bath-houses (saunas) by the river Vilnele; local breweries run by SMEs"33.

Upon evaluating the project, the participants in the workshop pointed out that one of the first steps should be to adapt the banks of Vilnele for recreation. It was suggested to preserve the natural terrain of the banks and to activate the areas intended for public use by constructing minor elements of landscape architecture in the water and along the banks. The experts believed that the entire territory of the Paupys should be developed as an authentic urban environment through restoring the channels in the Paupys area.

Water covers $2 \%$ of the total area of Vilnius $\left(7 \mathrm{~km}^{2}\right)$ : there are 50 dams, 16 lakes, 15 rivers and streams, but their functional potential remains to be realized. The identity of the city's inhabitants is not linked to any particular river or lake and is focused largely on the Gediminas Castle. As a consequence, rivers lose their potential role in an urban context. However, the younger generation of residents is interested in the history of Vilnius and attempts are made to recreate the forgotten symbols of the historical neighbourhoods and to return water aesthetics to the city in a longer-term perspective through architectural and urban development.

From the general overview of the situation with artificial and natural water in Vilnius, it is clear that the discourse in this sphere has just begun and is not included on the agenda among the most crucial current affairs, but people are already starting to pay more attention to this, and in the future, this attention could grow stronger, gain a greater significance and a more solid basis. It is obvious that relations between consumption society and nature always were conflicting and so stays in our time. However, the quality of environment, which typically was considered as external value, nowadays becomes internal one and for the individual it becomes natural to state it as

32 P. Baltrènas, E. Baltrènaitè, T. Kačerauskas, Social Environment of Creativity, "Filosofija Sociologija" 2015, vol. 26, no. 1, LMA leidykla, Vilnius, p. 46-54.

33 Vilniaus architektūros parkas - Projektas B-team [Vilnius architecture Park - Project Bteam], 2011, http://www.archparkas.vilnius.lt/lit/Renginiai/27285 [access: 01.08.2016]. 
such and defend it. Without high-quality environment it is not imaginable not only economic and ecologic welfare, but as well the future of humanity. Also, it becomes more obvious of environment influence to cultural and educational values as well to its importance of individuals and societies formation and improvement ${ }^{34}$.

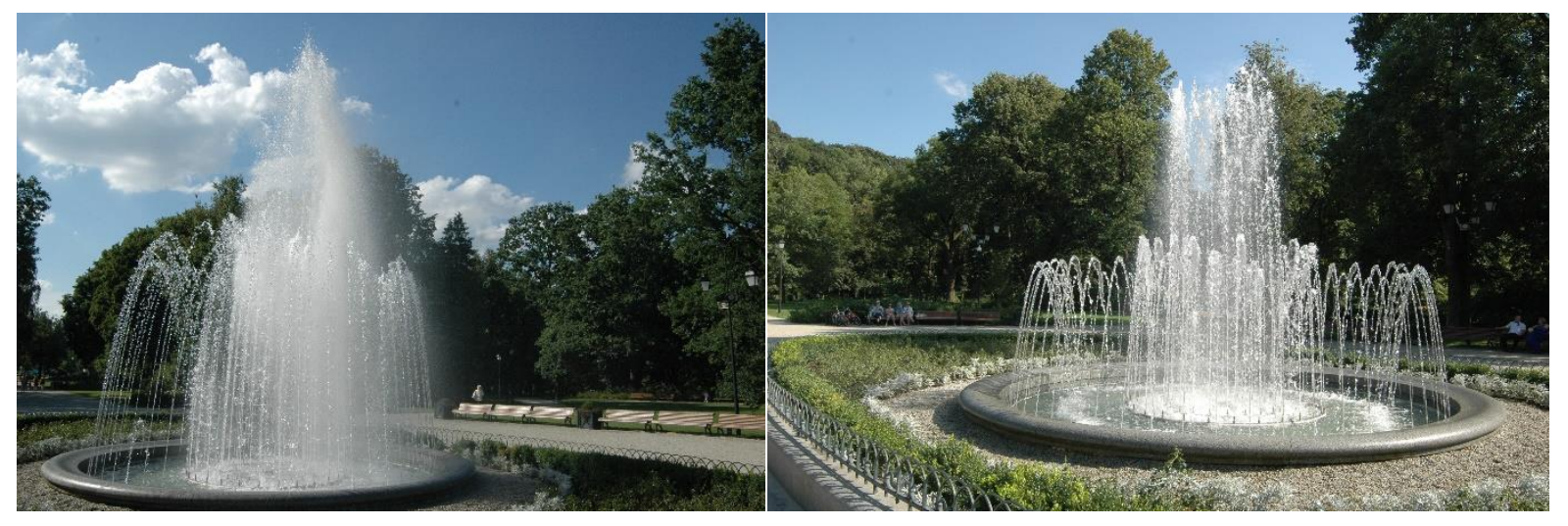

Music fountain in Vilnius, photo by A. Stančius

From a cultural and economic perspective, according to Thomas A. Hutton, contemporary cities are affected by different polycentric clusters of power, such as tourism, business, culture, government and so on. However, historically it came to be so that in each given city, specific technological, cultural and economic characteristics will shape a specific cultural economy. This is particularly true for mega-cities, such as London or Rome. However, as far as globalization is concerned, smaller cities, while not distinguished by any corporate concentration or power, may have one or more technological and cultural institution such as UNESCO, or a fine historical landscape ${ }^{35}$, which is particularly true in the case of Vilnius.

Thomas A. Hutton draws the reader's attention to the need to reconsider the urban areas while taking into account the relevant social and economic aspects, and to draw a connection between these areas and the creative industries, which, if one considers the priority of the city's economic, industrial and accommodation-related needs, remain fragmented, are left to random

34 V. Pruskus, Kūrybingumo panaudojimo gerinant aplinkos kokybę etiniai ir socialiniai kultūriniai aspektai [Ethical and Sociocultural Aspects of Creativity Use in Improving the Quality of the Environment], "Filosofija Sociologija" 2015, vol. 26, no. 3, LMA leidykla, Vilnius 2015, p. 201209.

35 Th. A. Hutton, Cities and the cultural economy, Routledge, London-New York 2016, p. 3943. 
gentrification and rarely acquire an aesthetic appearance ${ }^{36}$. Even without attracting particular attention to these processes, it is hardly surprising that the cultural platform "Kultflux" on the bank of the Neris lasted no more than a few years or that new art galleries and project spaces in Vilnius appear in the visually unappealing neighbourhood around the railroad and bus stations.

Thus, the current discourse on water installations, river banks, canals and even rainwater in Vilnius tends toward ideas related to the reconstruction of urban areas. The cultural trajectory of this process is yet to be defined more clearly; the issue has lost the bulk of its ideological weight and intersects with technology and with the interests of the capitalist economy and cultural industries. Foreign experts are invited to discuss the matter and to provide assistance. However, this is an indication that questions connected to the cultural value of water issues in the city of Vilnius are becoming more and more relevant.

\section{Results}

For historical reasons, due to factors that used to be present in the past, the Baltic peoples failed to develop a worldview characteristic for a maritime state with a culture of water, and, as a result, one cannot trace any cultural self-identification with water in the Lithuanian mentality.

The water installations constructed over the course of history were socially active and did not face any cultural resistance, which allowed them to influence the Lithuanian worldview. The first aesthetic water installations were associated with the Christian outlook on the world, while the later ones were more connected to secular Western European aesthetic standards. This influence tended to manifest as the nobility's desire to follow the latest fashions, though at first contemporaries perceived Baroque trends as related to the stylistic norms prevalent in neighbouring Warsaw, rather than to the local culture. Finally, the influence of E. F. Andre on aesthetic standards has left a deep mark on the Lithuanian mentality. Taken together, all of these influences failed to produce any clearer sense of self-identification with water in Lithuania.

Many recently built fountains in the public areas of Vilnius are linked to the Tsarist and Soviet occupation, and therefore have had more ideological and propagandist significance. Nevertheless, one can also detect numerous manifestations of resistance, such as the unique creativity of the architects, which helped encode the Lithuanian identity in a metaphorical form. Still,

36 Ibidem, p. 198-200. 
probably due to the fact that no strong cultural identification with water had been formed in the nation's historical consciousness, these installations came to be quire neglected and lost their significance after the political situation changed.

Recently, architectural manifestations of water culture began to become more relevant and significant, and have been turned into a subject for separate discussions. However, in the absence of a clear position and extensive experience, the importance of these phenomena has been underestimated, which, in turn, has contributed to the lack of any clear cultural trajectory in the city of Vilnius.

\section{References}

Miesto architektūra. Erdvés, formatai, akcentai [Urban Architecture. Spaces, Formants and Accents], “Acta Academia Artium Vilnensis" 2015, vol. 76, Vilniaus dailès akademijos leidykla, Vilnius 2015.

Aquinus T., Apie atskirtq̨ias substancijas [About Detached Substances], transl. G. Vyšniauskas, Visuomeninè organizacija "LOGOS", Vilnius 2009.

Balkevičius J., Sody meno stiliu raida [The Development of Gardens Art]. Vilniaus dailès akademijos leidykla, Vlnius 2010.

Baltrènas P., Baltrėnaitė E., Kačerauskas T., Social Environment of Creativity, "Filosofija Sociologija" 2015, vol. 26, no. 1, LMA leidykla, Vilnius, p. 46-54.

Bumblauskas A., Senosios Lietuvos istorija, 1009-1795 [The History of Old Lithuania, 10091795], R. Paknio leidykla, Vilnius 2005.

Butkus T. S., Water vision. A View on Waterside Development in Lithuania, "Project Baltia" 2007, no. 1: Water, PAR OU, Estonia, p. 58-59.

Eco U., Menas ir grožis viduramžiu estetikoje [Art and Beauty in Medieval Aesthetics], transl. J. Vilimas. Baltos lankos, Vilnius 1997.

Galaunè P., Lietuviu liaudies menas: jo meniniu formu plètojimosi pagrindai [Lithuanian Folk Art: the Basics of its Art Forms Evolution], L. U. Humanitarinių mokslų fakulteto leidinys, Kaunas 1930.

Heraclitus, Fragmentai [Fragments], transl. M. Adomėnas, Aidai, Vilnius 1995.

Hutton Th. A., Cities and the Cultural Economy, Routledge, London-New York 2016.

Jakovlevas-Mateckis K., Miesto kraštovaizdžio architektūra [Cities Landscape Architecture], Technika, Vilnius 2008.

Jakubavičienè I., Vartotojiškos visuomenès kuriamas Lietuvos miesto įvaizdis [Lithuanians City Image Created by Consuming Society], [in:] Kultūra ir miestas. Moksliniu straipsnių rinkinys, ed. Rimkutė A., Vilniaus universitetas, Vilnius. 2011.

Jurkštas J., Senojo Vilniaus vandenys [Waters of Old Vilnius], Mokslas, Vilnius 1990.

Kačerauskas T., Kaklauskas A., Kürybinis miestas: mitai ir utopijos [Creative City: the Myths and Utopias], "Filosofija Sociologija" 2015, vol. 25, no. 3, LMA leidykla, Vilnius, p. 190-199. 
Lavrinec J., Urbanistinè choreografija: kūnas, emocijos, ritualai [Urban Choreography: Body, Emotions, Rituals], "Santalka: Filosofija, Komunikacija" 2011, vol. 19, no. 1, LMA leidykla, Vilnius 2011, p. 62-73.

Le Corbusier, The City of Tomorrow and Its Planning, The Architectural Press, London 1947.

Mačiulis A., Architektūra - stiliai, kompozicija, menu squveika [Architecture - Styles, Composition, Art Interaction], VDA leidykla, Vilnius 1997.

Novickas A., Atminties ịprasminimas miesto aikštéje: nuo paminklo iki patirčiu erdvés [Memory-Actualization in the Town Square: from the Monument to the Experiences of Space], Technika, Vilnius 2010.

Pruskus V., Kūrybingumo panaudojimo gerinant aplinkos kokybę etiniai ir socialiniai kultūriniai aspektai [Ethical and Sociocultural Aspects of Creativity Use in Improving the Quality of the Environment], "Filosofija Sociologija" 2015, vol. 26, no. 3, LMA leidykla, Vilnius 2015, p. 201-209.

Samalavičius A., Idejjos ir struktūros architektūros istorijoje [Ideas and Structures of Architectural History], Kultūros barai, Vilnius 2004.

Samalavičius A., Nelaisvés formos. Almanto Samalavičiaus pokalbiai apie ekonomika, miestokūrą ir krizes [Captivity Shape. Almantas Samalvicius Talks About Economy, City Development and Crisis], Kultūros barai, Vilnius 2014.

Symmes M., Fountains Splash and Spectacle, Smithsonian Institution, Singapore 1998.

Skripkiūnas G., Statyba ir architektūra [Construction and Architecture], Proceedings of the Conference, Technologija, Kaunas 1998.

Štelbienè A. Vanduo Lietuvos architektūroje sausumos gyventojo akimis [Water in Lithuanian Architecture in the Eyes of Landsman], "Archiforma", Ex Arte, no. 4, Vilnius 2000, p. 75-80.

Vilniaus architektūros parkas - Projektas B-team. [Vilnius Architecture Park - Project Bteam], 2011, http://www.archparkas.vilnius.lt/lit/Renginiai/27285 [access: 01.08.2016].

\section{Streszczenie}

\section{Przemiany w kulturze urbanistycznej i rola wody w środowisku miejskim - na przykładzie Wilna}

Artykuł przedstawia powiązania między wodą, rozumianą jako medium architektoniczne, a kulturą Wilna. Głównym celem jest określenie społecznej i estetycznej roli, jaka woda pełni w rozwoju wileńskiej architektury, przy uwzględnieniu przemian w obszarze wartości i koncepcji dotyczących urbanistycznego design. W architekturze Wilna woda odbija zasady funkcjonalności i artystycznych koncepcji charakterystycznych dla kilku różnych okresów. konkluzji stwierdzam, że powiązania między wodą a litewską tożsamością kulturową są słabe, zatem to architektoniczne medium było raczej używane przez zewnętrzne siły jako środek społecznej sugestii, niż do zaspokajania wewnętrznych potrzeb kultury litewskiej. Niemniej prowadzone obecnie dyskusje niosą pewien potencjał, gdy idzie o przyszłą zmianę. 
Słowa kluczowe: woda, architektura, estetyka, fontanny Wilna, kultura miejska, urbanizacja

\section{Zusammenfassung}

\section{Der Wandel in der urbanen Kultur und die Rolle des Wassers in der städtischen Umwelt - auf dem Beispiel von Wilna}

Im Artikel werden die Beziehungen zwischen dem Wasser als architektonischem Medium und der Kultur von Wilna dargestellt. Das Hauptanliegen ist dabei die Bezeichnung der sozialen und ästhetischen Rolle des Wassers in der Entwicklung der Wilnaer Architektur unter Berücksichtigung des Wandels im Bereich der Werte und Konzepte des urbanen Designs. In der Architektur von Wilna spiegelt das Wasser die Grundsätze der Funktionalität und der künstlerischen Konzepte wider, die für einige unterschiedliche Epochen charakteristisch waren. In der Schlussfolgerung stelle ich fest, dass die Beziehungen zwischen dem Wasser und der litauischen Kulturidentität schwach sind, so dass dieses architektonische Medium eher durch äußere Kräfte als Mittel der sozialen Suggestion, als zur Befriedigung der inneren Bedürfnisse der litauischen Kultur verwendet wurde. Die aktuell geführten Diskussionen haben jedoch ein Potenzial für zukünftigen Wandel.

Schlüsselworte: Wasser, Architektur, Ästhetik, Springbrunnen von Wilna, städtische Kultur, Urbanisierung

Informacja o autorze:

ANTANAS STANČIUS, członek Lithuanian Interdisciplinary Artists' Association, doktorant w dziedzinie architektury krajobrazu, Uniwersytet Kłajpedzki, Litwa; adres do korespondencji: Architecture, Design and Art Department, Klaipeda University, K. Donelaičio ave. 5, LT-92144 Klaipeda, Lithuania; e-mail: stancius.antanas@gmail.com 